\title{
JAPAN AND "THE OTHER": RECONCEIVING JAPANESE CITIZENSHIP IN THE ERA OF GLOBALIZATION
}

Catherine Lu, Toshihiro Menju, and Melissa Williams

The era of globalization has produced increasing social diversity within Japanese society, forcing a reexamination of mainstream assumptions about Japanese national identity and citizenship. Local government and civil-society responses to social diversity have led to the blossoming of internationalization and "sister city" movements. At the national level, however, clear leadership supporting reform of national immigration and citizenship policies has been lacking. Should Japan choose the path of accepting internal diversity as a permanent feature of its society, and doing so on terms that are consonant with ideals of democratic egalitarianism, it may benefit from examining the citizenship policy reforms fashioned by other democratic societies in response to social and cultural diversity, such as notions of "denizenship" and multicultural citizenship. Such reforms that confirm the equal dignity of social "others" would also support Japanese citizens more broadly to adopt heterogeneous rather than homogeneous notions of Japanese national identity.

Key words: citizenship, ethnonationalism, immigration policy reform, Japan, Okinawa 


\section{Introduction: \\ Challenges for Japanese Understandings of Citizenship}

The history of Japan's journey towards modern statehood has been marked by competing and sometimes conflicting discourses on Japanese identity. On the one hand, as both Japanese and European projects of state building in the nineteenth century make clear, the creation of a modern state entails the consolidation of a unified citizenry that recognizes the state as the exclusive source of political authority and exclusive site of political loyalty and attachment. This dimension of modern state building generated an ethos of equality before the law for all Japanese subjects and sought to erase class distinctions in favor of the status of equal and universal Japanese citizenship. At the same time, in Japan as in other modernizing states, the quest for a unitary and single-minded citizenry encouraged a distrust of identities that apparently diverged from a standardized ideal of the "good citizen."1

On the other hand, the creation of the modern state in the European context was tightly connected to colonialism as a source of economic resources for internal state building and as a demonstration of state power and cultural superiority. Because Japan's modernization under the Meiji Restoration was so closely modeled on the European experience, and was sparked by a felt need to protect Japan from European imperialism, the project of modern Japanese statehood generated an imperial project whose ideological justification was grounded in the superiority of Japanese culture to the cultures of surrounding Asian societies. Japanese imperialism, like European, wrapped itself in the mantle of a civilizing mission aimed at bringing Japan's Asian neighbors up to its own level of economic and cultural development. At the same time, colonized peoples were recognized as Japanese subjects who had a claim to equal treatment before the law.

1. For an historical account of racist and nativist influences in the formation of the American state and of conceptions of U.S. citizenship, see Rogers Smith, Civic Ideals: Conflicting Visions of Citizenship in U.S. History (New Haven: Yale University Press, 1997); for a similarly masterful account of cultural and racial hierarchy in the formation of the Canadian law, see James W. St. G. Walker, "Race," Rights and the Law in the Supreme Court of Canada (Waterloo, Ontario: Wilfrid Laurier University Press, 1997).
The combination of these two strands of ideology-equal citizenship status for all Japanese subjects plus Japanese cultural superiority-has historically generated a strong state policy of assimilation of those ethnic minorities that are regarded as a permanent presence in Japan. For most of Japan's modern history, ethnic minorities have not been wholly excluded from Japanese citizenship (with the exception of Koreans, Chinese and Taiwanese in the postwar period), but the condition for citizenship has been the abandonment of minorities' cultural identity and a full embrace of Japanese culture. At the same time, discourses of Japanese cultural superiority, and the fear that Japanese culture might be undermined by foreign influences, have contributed to producing historic patterns of discrimination even toward those who were willing to assimilate. For some minorities, this has meant a choice between living on the fringes of Japanese society or accepting second-class citizenship; both choices deny them acceptance as full members of Japanese society.

At the same time, Japan's desire to establish itself as a full and respected member of international society in the postwar period, and its economic interests in building strong ties to other countries in Asia and globally, have led some Japanese (especially within nongovernmental organizations [NGO] circles) to embrace a more global conception of citizenship. One expression of these inclinations, discussed in more detail below, is the internationalization and "sister city" movement that sprang up in the postwar period and further blossomed during the "bubble economy" of the 1980s. Another is Japan's involvement in humanitarian and refugee relief efforts in recent years, including its acceptance of Indochinese refugees beginning in the late 1970s, and its subsequent commitment to various international human rights covenants. The globalized conception of citizenship implicit in these trends fits well with the egalitarian ethos of universal citizenship, and supports a Japanese identity that is welcoming of cultural diversity and generous in its humanitarianism. At the same time, these features of global citizenship sit uneasily with discourses of Japanese identity that emphasize cultural homogeneity and the fear of foreignness as a threat to Japanese stability.

Since the years of the "bubble economy," the immigration of foreign workers to supplement the Japanese labor force has markedly increased the number of foreign residents in Japan. 
Although immigration has not grown as significantly during the years of recession, it is reasonable to suppose that a robust economic recovery will renew the need for foreign labor. Japan's aging population portends a shrinking workforce (and the need for a growing cadre of care workers), even if we account for the entry of increasing proportions of women into the paid workforce. Offshore production by Japanese firms may offset or delay the need for immigrant labor, but many commentators predict that increasing immigration is a nearly inevitable feature of Japan's future. ${ }^{2}$

Meanwhile, advocates for Japan's minority communitiesAinu, Koreans, and burakumin, to name the most significant groups -have been more vocal in recent years in claiming recognition of their equality and cultural rights in Japanese law and society. These movements appear to be gaining strength in recent years, and are unlikely to disappear from the Japanese political scene. Their claims are grounded in moral arguments that are strikingly similar to those of minorities in other liberal democratic societies, and it seems likely that they will continue to seek gains similar to those that minorities have achieved elsewhere.

Japan thus dwells in the same era of globalization and diversity that is reshaping so many other liberal democratic societies. Yet at the policy level, the national government appears to lack a clear policy direction for coming to terms with the current and future realities of diversity in Japanese society. Recent developments in the theory and practice of citizenship and multiculturalism may be of some use to Japanese policymakers and scholars in fashioning a response to diversity that is consonant with the principle of democratic equality, reflective of the interest in maintaining Japanese culture, and respectful of the cultural diversity that exists in contemporary Japan.

2. See, for example, Demetrios G. Papademetriou and Kimberly A. Hamilton, Reinventing Japan: Immigration's Role in Shaping Japan's Future (Washington, D.C.: Carnegie Endowment for International Peace, 2000), pp. 38-42.

\section{Japanese Encounters with Diversity: \\ A Brief Historical Sketch}

By reputation Japan is one of the most ethnically and culturally homogeneous societies in the world. As an empirical matter, there is considerable truth in this claim: Sociological measures of diversity give Japan the lowest score, along with such countries as Iceland, Jordan, the Koreas, and Morocco. ${ }^{3}$ Currently, foreign residents of Japan-non-Japanese citizens-compose only about 1.5 percent of the country's total population. ${ }^{4}$ Japan's relative cultural homogeneity is frequently traced to its status as an island nation characterized by long periods of seclusion from the rest of the world, especially during the 350 years of Tokugawa rule. In the Tokugawa period, foreigners were banned from Japan except for a small number of key trading ports, especially Nagasaki, where they were restricted to limited enclaves and prohibited from mingling with the general Japanese population.

At the end of the Tokugawa period, the non-Japanese population in Japan, comprised mainly of Dutch and Chinese traders, was restricted to enclaves in Nagasaki. Meiji reformers sought to increase Japan's openness to foreign knowledge, and brought many foreign advisors to Japan to inform the process of modernization in law, business, infrastructure, and industrial technology. In this "opening" of Japan, however, Meiji leaders did not contemplate the creation of a population of long-term resident foreigners within Japan. Rather, the expectation was that foreign advisors were temporary visitors who would return to their home countries once their work was done, as indeed most did. "Opening" Japan to foreign expertise did not entail opening Japan's borders to immigration.

The astonishing success of Meiji leaders in modernizing the Japanese economy, society, and polity within a very short time depended not only on introducing technological and financial

3. Country Indicators for Foreign Policy, online at www.carleton.ca/cifp/ rank.htm. These countries rank 1 on a 9-point scale for diversity; Canada ranks among the most diverse countries, with a score of 9, and the United States scores 4.

4. There were 1.915 million registered foreign residents in Japan as of December 31, 2003. See Statistics on the Foreigners Registered in Japan (Tokyo: Japan Immigration Association, November 2004), p. 1. 
changes, but also a dramatic transformation of the legal system. The replacement of the han system with prefectures as territorial units for the administration of a central and uniform legal system was crucial to establishing the political authority of the central government throughout the provinces and to instituting policies aimed at creating a national citizenry. Universal compulsory education and military conscription were key instruments in transforming peasants and nobles into (formally) equal Japanese citizens.

The institutions of universal Japanese citizenship were in many ways progressive, insofar as they formally abolished most class distinctions under law and laid the foundations for a meritocratic system of careers open to talents. Even the burakumin, the outcaste of workers who, in traditional society, performed the tasks associated with ritual pollution, were formally included in the new universal citizenship, although in practice they continued to be subject to egregious discrimination. Yet for the indigenous Ainu people in the north and the Okinawans in the south, Meiji policies were not experienced as emancipatory. These peoples, culturally and linguistically distinct from the majority population, had lived on the fringes of Tokugawa power structures and had some degree of autonomy under the Tokugawa regime. Meiji policies of uniform citizenship included radical programs of assimilation for Ainu and Okinawan populations. In a pattern similar to the "internal colonization" of indigenous peoples in the United States, Canada, Australia and New Zealand, Ainu traditional lands were appropriated by the state, depriving the Ainu of their traditional economy (predominantly a fishing and hunting economy) and forcing them into an unfamiliar agricultural lifestyle. In education, both Ainu and Okinawans were forbidden to speak their native languages and required to learn the standard version of Japanese language; the express policy of the Meiji regime was to "Japanize" these populations and "bring them up" to the level of Japanese civilization. From the standpoint of Meiji reformers, these policies of assimilation probably appeared progressive, insofar as they were based on the premise that cultural minorities, like the Japanese peasantry, were capable of being raised up to become full Japanese citizens. Nonetheless, it is difficult to separate assimilationist programs from beliefs about the cultural backwardness of the
Ainu and Okinawan peoples.

Ethnonationalism as a distinct discourse of state ideology did not emerge clearly until the early twentieth century; during the early Meiji period, nationalist discourses were advanced primarily in terms of the need for defense against European and American imperialism and in the interest of state building. ${ }^{5}$ Japan's superiority as an Asian culture that had demonstrated that it was equal to the challenges of modernity was used as a justification for its colonization and annexation of Taiwan in 1895 and of Korea in $1910 .^{6}$ The civilizational rationale of annexation entailed that Koreans and Taiwanese were officially Japanese subjects and citizens, formally entitled to equal status under law with ethnic Japanese citizens. In practice, of course, colonial subjects were mainly exploited as workers and, for the most part, were excluded from the ranks of colonial officials. The extraction of the agricultural surplus from Korea impoverished the countryside and led to a significant Korean (and a smaller Taiwanese) migration to Japan, where they performed work that most Japanese were unwilling to perform. Thus colonialism generated a new form of ethnic diversity within Japan. As Japanese citizens, these populations were eventually included in the universal education system. ${ }^{8}$ During the Second World War, the need for additional labor, especially in the manufacturing and coal mining industries, led to further voluntary migration as well as involuntary conscription of Korean workers in Japan. By war's end, the Korean

5. Chikako Kashiwazaki, “Jus sanguinis in Japan: The Origin of Citizenship in a Comparative Perspective," International Journal of Comparative Sociology, vol. 39, No. 3 (1998), pp. 278-301; see also Kevin M. Doak, "Ethnic Nationalism and Romanticism in Early Twentieth-Century Japan," Journal of Japanese Studies, vol. 22, No. 1 (1996), pp. 77-103, p. 82: "Early cultural nationalists in Meiji Japan, such as Miyake Setsurai and and Shiga Shigetaka, had ... emphasized the particularity of Japanese culture, but they located this need for cultural appreciation within the larger paradigm of state-building as ideally strengthening the state. In the early years of the twentieth century, as Japan prepared for war against Russia, ethnic nationalism (minzokushugi) began to appear in powerful if still inchoate form."

6. Michael Weiner, Race and Migration in Imperial Japan (London: Routledge, 1994), pp. 21-37.

7. Ibid., pp. 45-50.

8. Ibid., pp. 98-105. 
population in Japan is estimated to have been 2 million. After a period of major re-migration, the Korean population in Japan stood at about half a million, and approximately 35,000 Taiwanese and mainland Chinese remained in Japan. ${ }^{9}$ Former colonial subjects remaining in Japan were stripped of their citizenship by the 1952 nationality law, 10 but were later recognized as "special foreign residents" with the right to settle permanently in Japan, but without the rights of citizenship. The postwar period thus produced, especially in manufacturing cities, significant local populations of non-Japanese populations without legally enforceable rights.

\section{The New Immigrants}

In the 1970s and 1980s, the labor shortage generated by Japan's "economic miracle" led to a new wave of immigration. Most of this influx was in the form of "technical traineeships" whose ostensive purpose was to provide training to foreigners for limited periods of time, on terms advantageous to their employers. Like the admission of foreign advisors during the early Meiji period, this policy was formally based on the assumption that the presence of these foreigners in Japan was a temporary phenomenon, and that they would leave as soon as their training was complete. In reality, however, many workers stayed beyond the terms of their traineeship. Meanwhile, the labor shortage made it possible for many who had come to Japan on visitor visas to find illegal employment and to stay beyond the terms of their visas.

Women comprise two distinct subsets within the wave of immigration since the 1980s. Immigration laws define several categories of immigration, one of which is "entertainers." Women from a variety of Asian countries comprise a significant proportion of this visa class. Many foreign women also work illegally in

9. Chikako Kashiwazaki, "From Immigration Control to Immigration Policy?" in Migration Information Source, online at www.migrationinformation. org/Profiles/display.cfm?id=39; Conrad Totman, A History of Japan (Oxford: Blackwell, 2000), p. 485.

10. For a brief discussion, see Keizo Yamawaki, "Foreign Workers in Japan: A Historical Perspective," in Mike Douglass and Glenda Roberts, eds., Japan and Global Migration: Foreign Workers and the Advent of a Multicultural Society (London: Routledge, 2000), p. 48. the food and entertainment industry, a phenomenon traceable in part to their ineligibility for employment as domestic workers, nurses, or factory workers. In addition, the depopulation of rural Japan, and the declining willingness of Japanese women to live as farmers' wives, has produced a market in "mail-order brides," many of whom come from the Philippines. ${ }^{11}$

To address the problem of illegal "visa overstayers" while also meeting Japanese firms' needs for additional labor, the national government revised its immigration laws in 1990. Some of these reforms were aimed at cracking down on illegal workers by punishing employers and by deporting those who overstayed their visa. The most important provision, however, provides that Nikkeijin, second- or third-generation descendants of Japanese citizens who emigrated to other countries, could "return" to Japan as residents entitled to work. During the 1990s, approximately 272,000 Nikkeijin, mostly from Brazil, settled in Japan. ${ }^{12}$ They are distributed across several prefectures, but are concentrated in such manufacturing cities as Hamamatsu, Toyoda, Tohohashi, Fuji, Yokkaichi, and Ohta. Although they are ethnically Japanese, many arrive with little familiarity with Japanese customs and without any knowledge of the Japanese language. Thus culturally they are significantly different from the mainstream Japanese population. Integrating this new class of foreign residents has proven challenging, particularly in the absence of any formal integration policy at the national level. Although the change in immigration policy appears to have been aimed at solving the labor shortage with an immigrant population that would easily assimilate into Japanese society, this has not proceeded as smoothly as policymakers appeared to believe it would.

Immigrants can be separated into two broad classes of foreign residents in Japan: the "oldcomers" who arrived before and during World War II, and the "newcomers" who, as we have seen, are themselves a diverse lot. The needs of these two groups

11. Takamichi Kajita, "The Challenge of Incorporating Foreigners in Japan: 'Ethnic Japanese' and 'Sociological Japanese'," in Myron Weiner and Tadashi Hanami, eds., Temporary Workers or Future Citizens? Japanese and U.S. Migration Policies (New York: New York University Press, 1998), pp. 142-43.

12. Hiroshi Komai, Foreign Migrants in Contemporary Japan (Melbourne: Trans Pacific Press, 2001), Table 1.1.3, p. 23. 
are quite different from one another. Oldcomers are familiar with Japanese customs and are fluent in Japanese. Many have successfully integrated into Japanese society. Although many continue to resist assimilationist pressures, the challenges they face are very different from the language and cultural barriers confronted by newcomers. ${ }^{13}$ Yet a further group comprises foreign students, mostly Chinese, who numbered almost 100,000 in 2003. Partially in response to fears of criminality among foreigners, the number of student visas issued to Chinese nationals has dropped significantly in 2004 . $^{14}$

Future patterns of immigration to Japan remain unclear. Nikkeijin continue to immigrate, though other immigration has slowed during the economic recession that followed the "bubble economy." If the economy continues to recover, however, it seems likely that a new labor shortage will eventually materialize. Offshore production in nearby Asian countries will function as a brake on immigration needs, but may not be sufficient to counterbalance Japan's declining workforce. The aging of Japan's population not only affects the number of new entrants into the workforce, but also generates a need for increasing numbers of care workers for the elderly, another potential source of immigration needs. Meanwhile, Japan's refugee policy has focused on providing support to refugee populations outside Japan rather than on accepting further refugees; therefore, refugee populations are unlikely to be a significant source of new immigration. Over all, it seems likely that Japan will need to consider increased immigration if and when it experiences a full economic recovery.

\section{Indigenous Peoples}

Beyond immigration, the facade of Japanese homogeneity obscures several internal sources of diversity. Three will be discussed briefly here: the Ainu, Okinawans, and burakumin.

Official Japanese statistics place the Ainu population on the

13. For further discussion, see Kajita, "The Challenge of Incorporating Foreigners in Japan," pp. 139-41.

14. Alan Brender, "In Japan, Protection or Prejudice? Government Slashes Number of Visas Issued to Chinese Students," Chronicle of Higher Education, May 28, 2004 island of Hokkaido at approximately 23,000 (though the Hokkaido Ainu Association offers a much higher estimate of 100,000). An indigenous northern people, the Ainu's traditional homeland included Ainu Moshiri (renamed Hokkaido by the Meiji regime in 1868), Sakhalin Island, and the Kurile Islands. As noted above, the Meiji regime advanced a policy of assimilation toward the Ainu; the main legal instrument for this policy was the Hokkaido Former Aboriginal Protection Act (1898). The use of the Ainu language was banned, and (following an initial period of separate education for "former natives") children were gradually integrated into Japanese schools. Like British colonial governments in Australia and Canada, the national government declared Hokkaido terra nullius (empty land), removing Ainu from their traditional lands, resettling Japanese farmers on the island, and attempting to train the Ainu into an agricultural economy.

Since the 1970s, inspired in part by transnational movements for indigenous rights, the Ainu have reasserted their cultural distinctiveness and sought recognition for their indigenous culture by the Japanese government. In 1997, the Sapporo District Court ruled that the Ainu should be recognized as an indigenous people under international law, and shortly thereafter the national government rescinded the Former Aboriginal Protection Act and established instruments for promoting Ainu language and culture. ${ }^{15}$ Although Ainu leaders applauded this legislation as a significant advance for their people, they are critical of its failure to address their claims for rights to traditional lands and for special representation in local and national legislative bodies. Thus far, the national government has been unwilling to recognize any Ainu claims that, in its view, rise to the level of claims to Ainu sovereignty, including land rights, restoration of resources, or payment of indemnities.

Okinawans (of whom there are approximately 1.2 million) are not recognized as an official minority by the Japanese government, but remain culturally distinct. Historically, Okinawa functioned as a quasi-independent territory (the Ryūkyū Kingdom) with fealty to China. This fealty was later transferred (albeit

15. Law for the Promotion of Ainu Culture and for the Dissemination and Advocacy for the Traditions of the Ainu and the Ainu Culture (May 1997). 
ambiguously) to Tokugawa Japan, but the region retained significant local autonomy. In 1879, it was officially incorporated into Meiji Japan as Okinawa Prefecture. As in Hokkaido, the Meiji regime advanced a strong policy of assimilation in Okinawa, extending military conscription to Okinawans in 1898, introducing common (Japanese) schooling at the primary level, and redesignating traditional shrines as state Shinto shrines. The dialects spoken in Okinawa are markedly different from standard Japanese, and the Meiji assimilation policy banned their use. As in Korea and Taiwan under Japanese rule, locals were prevented from holding political or civil service positions.

The horrific Battle of Okinawa, and the ensuing American occupation of the region until 1972, have left scars on Okinawan society and contributed to a sense of marginalization within Japan. Eleven percent of Japanese territory is still claimed by military bases, and Okinawans remain resentful of the significant American military presence there, in part because of abuses by American soldiers (including the notorious kidnapping and rape of a 12year-old Okinawan girl in 1995). Although discrimination against Okinawans in other parts of Japan has decreased markedly in recent years, there remains an enduring sense that Okinawans are second-class citizens within Japan. Okinawan leaders and activists continue to claim greater local autonomy, support for Okinawan language and culture, and economic restitution for lands taken for military purposes. ${ }^{16}$

Burakumin are not a culturally or racially distinct group in Japan, but generations of economic marginalization and discrimination have left them in a position of disadvantage within Japanese society. Because of discrimination in employment, marriage, and education, buraku populations have become concentrated in communities with poor housing, schools, and social services compared with the rest of Japan. The overall consequence of this history is that burakumin continue to live in a position of

16. See especially Assimilation Practices in Okinawa (Okinawa Peace Network of Los Angeles, [cited May 22, 2004]); online at www.unchinanchu.org/ uchinanchu/history_assimilation.htm; JuliaYonetani, "Future 'Assets,' but at What Price? The Okinawa Initiative Debate," in Laura Hein and Mark Selden, eds., Islands of Discontent: Okinawan Responses to Japanese and American Power (Lanham, M.D.: Rowman \& Littlefield, 2003), pp. 243-72. systemic disadvantage, with higher rates of unemployment, school dropout, and poverty than other Japanese citizens. In part as a response to buraku activism, the occupation government established special Dōwa districts as units of government administration. These districts now provide the site for educational and economic development projects aimed at ameliorating the inequality of burakumin within Japan. The Buraku Liberation League continues to advocate actively for an improvement in the circumstances of the burakumin.

In sum, Japan's population contains a number of significant minorities: ethnic Korean residents and citizens, including both "oldcomers" and "newcomers"; Nikkeijin from Brazil and Peru; Chinese and Taiwanese residents (with some "oldcomers" among them); Filippinos; Ainu, Okinawans, and burakumin. ${ }^{17}$ These groups constitute broadly different dimensions of diversity within Japan, and pose distinct challenges to the formation of an inclusive and egalitarian conception of Japanese identity and national citizenship.

\section{International Human Rights Norms and the Evolution of Japanese Citizenship}

Japanese conceptions of nationality, identity, and citizenship have been influenced by external ideas, especially from the West. The Meiji Constitution of 1889 adopted German Rechtsstaat principles from the 1850 Prussian Constitution that granted weak rights to subjects, whose "rights and freedoms did not inherently belong to individuals, but were granted to Japanese citizens by the State as subjects of the Emperor who was sovereign." ${ }^{18}$ Late nine-

17. The approximate numbers within these population groups are as follows: Korean residents, 625,000; Nikkeijin, 276,000; Chinese/Taiwanese residents, 424,000; Filippino residents, 169,000; other foreign residents, 633,000; Ainu, 25,000; Okinawans, 1.2 million; Burakumin, 3 million. See Komai, Foreign Migrants in Contemporary Japan, Table 1.2, p. 29.

18. Mark Levin, "Essential Commodities and Racial Justice: Using Constitutional Protection of Japan's Indigenous Ainu People to Inform Understandings of the United States and Japan," New York University Journal of International Law and Politics, vol. 33, No. 2 (2001), pp. 419-526 at p. 474. See also Richard Siddle, "The Limits of Citizenship in Japan: Multiculturalism, 
teenth-century European racial ideology permeated the Japanese encounter with the concept of "nation," subsequently shaping the development of the Yamato minzoku, "the Japanese "race' /nation," that combines "the primordial ties of language, culture and blood under the leadership of the Emperor, in the vast fictive kinship system of the 'family state' (kazoku kokka)."19

The postwar period witnessed the near universal repudiation of nineteenth-century European racial theories and eventually spawned domestic and global political, legal, and social transformations, from the recognition of the sovereign equality of former colonies in international law, to the entrenchment of human rights charters and antidiscrimination laws at national and international levels. Just as modern Japanese notions of nationality and citizenship emerged from contact with the West, the linkage between international human rights norms and Japanese domestic law was also forged through such contact in the wake of Japanese defeat in the Second World War. The postwar Japanese constitution contains human rights provisions, but only as a result of a compromise between the Supreme Command of the Allied Powers in the Pacific and the Japanese government. Throughout the drafting process, the latter consistently attempted to restrict legal protections for non-Japanese and other "disfavored" groups. ${ }^{20}$ In 1952, Japan passed nationality legislation under the new constitution, stripping Koreans, Taiwanese, and mainland Chinese of the citizenship status they had possessed in imperial Japan. This law also entrenched patrilineal jus sanguinis citizenship: The citizenship status of one's father determined one's citizenship under Japanese law.

Currently, permanent residents are permitted to apply for naturalization after five years; spouses and children of Japanese nationals may apply after one year. Although Japanese naturalization requirements have historically had a strong assimilationist bias, this has been somewhat relaxed in recent years. For example,

Indigenous Rights and the Ainu," Citizenship Studies, vol. 7, No. 4 (2003), p. 450 .

19. Siddle, "The Limits of Citizenship in Japan," p. 450

20. Claire J. Hur, “Comment: Returnees from South America: Japan's Model for Legal Multiculturalism?" Pacific Rim Law \& Policy Journal, vol. 11, No. 3 (June 2002), pp. 669-71 until 1985 applicants were required to adopt Japanese names in order to be eligible for citizenship, an important barrier for ethnic Korean "oldcomers" who did not wish to abandon their Korean names as a condition of naturalization. Nonetheless, current law still requires that citizens' names be inscribed in Japanese characters, which rules out some Korean names. ${ }^{21}$ Naturalization decisions are made on a case-by-case basis without clearly stated criteria for approval, and this creates the appearance of arbitrariness - and of ongoing assimilationist pressures-in the naturalization process. ${ }^{22}$ Dual nationality is possible only for children up to age twenty-two, at which time the individual must choose. An increasing rate of international marriages has generated some pressures to permit dual citizenship, but the national government does not appear inclined to accept this change.

All told, Japan has a lower naturalization rate than other developed countries in the Organization for Economic Cooperation and Development (OECD). ${ }^{23}$ Many Koreans are reluctant to be naturalized because of the historical legacy of Japanese colonialism, and because they find the conception of Japanese nationality problematic as it is currently constructed. ${ }^{24}$ Article 5 of the constitution deprives naturalized Japanese nationals of their former nationality, and Article 11 stipulates that Japanese nationals lose their Japanese nationality when they acquire another nationality. The fear of total assimilation led some Korean groups to claim that the policy of fingerprinting before 1993 was an important consciousness-raising experience for young Koreans to identify as Koreans rather than as members of Japanese society. ${ }^{25}$

In recent decades, Japan has ratified several major international human rights covenants and conventions, including the International Covenant on Civil and Political Rights (ICCPR-1979),

21. Papademetriou and Hamilton, Reinventing Japan, p. 45.

22. Ibid

23. Atsushi Kondo, "Development of Immigration Policy in Japan," Asia and Pacific Migration Journal, vol. 11, No. 4 (2002), pp. 415-36.

24. See Erin Aeran Chung, "Exercising Citizenship: Koreans Living in Japan," Asian Perspective, vol. 24, No. 4 (Winter, 2000), pp. 159-78; and Atsushi Kondo, "Citizenship Rights for Aliens in Japan," in A. Kondo, ed., Citizenship in a Global World: Comparing Citizenship Rights for Aliens (New York: Palgrave, 2001), pp. 8-30.

25. Chung, "Exercising Citizenship," pp. 164-65. 
the International Covenant on Economic, Social and Cultural Rights (ICESCR-1979), the Convention Relating to the Status of Refugees (1982), the Convention on the Elimination of All Forms of Discrimination Against Women (1985), the Convention on the Rights of the Child (1994), and the Convention on the Elimination of All Forms of Racial Discrimination (1995). ${ }^{26}$

Japan's formal commitment to international covenants has spawned significant challenges and changes in the interpretation of domestic laws, affecting the evolution of Japanese citizenship. ${ }^{27}$ After acceding to the Convention on the Elimination of All Forms of Discrimination Against Women in 1985, for example, Japan modified its citizenship law to allow citizenship status at birth to follow the mother's as well as the father's citizenship. To take another example, Article 25 of the Japanese constitution- "All nationals shall have the right to maintain the standards of wholesome and cultured living" - was interpreted restrictively, to apply only to Japanese nationals. With the acknowledgement of the International Covenant on Economic, Social and Cultural Rights, however, the Japanese government has had to adopt a more expansive interpretation of the article, to recognize the social rights of aliens, because the ICESR commits states to "recognize the right of everyone to social security, including social assistance." 28

The struggle for political, civil and social equality within Japan has entailed legal and political challenges that have invoked international human rights standards and laws. Although Japanese courts have used international law to clarify domestic law, they have generally deferred to a conservative central government. As a result the constitutional rights that are granted to all in theory are enjoyed unevenly, with ethnic minorities enjoying far fewer protections. ${ }^{29}$ Still, disadvantaged groups in Japan, such as women,

26. John Peek argues that the Japanese government has been a reluctant participant in international human rights activities; in 1992, it had "ratified only seven of the 22 human rights treaties passed by the U.N." See John M. Peek, "Japan, the United Nations, and Human Rights," Asian Survey, vol. 32, No. 3 (March, 1992), p. 221.

27. Yuji Iwasawa, "The Domestic Impact of International Human Rights Standards: the Japanese Experience," in The Future of UN Human Rights Treaty Monitoring (Cambridge: Cambridge University Press, 2000), pp. $245-68$.

28. See Hur, "Comment: Returnees from South America," pp. 643-86. the Ainu, foreign workers, and the burakumin, have all successfully used international human rights mechanisms, such as the United Nations Human Rights Commission, to pressure the Japanese political elite to enact modest social reform. ${ }^{30}$

The international human rights framework has, for example, affected two significant cases within Japan. In one case, due to internal and international protests, the practice of fingerprinting permanent resident aliens was discontinued in 1993; by 2000, the practice was abandoned for all aliens. Although the court ruling did not appeal directly to the International Covenant on Civil and Political Rights, it did argue that there "was room to suspect" that the policy of fingerprinting violated several ICCPR articles. The ruling also referred to general comments and views of the UN Human Rights Commission, the European Commission on Human rights, and a European Court of Human Rights ruling. In another case, wounded veterans of Korean descent who fought for Japan sought compensation from the Japanese government by invoking the ICESR and ICCPR. The Tokyo court did not directly acknowledge the case as a violation of the international covenants, but admitted that "the arguments of the plaintiff contain some points worth listening to." ${ }^{\prime 3}$

The issue of political, civil, and social equality for minorities in Japan, however, is more complicated than that of obtaining equal benefits for veterans, or eliminating discriminatory identification policies. As noted above, the dominant trend has been the increasing integration of permanent resident aliens within local communities, but continual lack of political rights or participation at the state level.

The dilemmas faced by ethnic minorities seeking inclusion in Japanese society reveal the tensions between two interpretations of the politics of recognition. ${ }^{32}$ As Charles Taylor has argued, the

29. Ibid., p. 668. Hur argues, "Despite recent events that appear to indicate positive steps toward recognition of the rights of ethnic minoritiessuch as the Ainu rights case and proposed legislation that would give voting rights to Korean permanent residents-the Japanese government continues to take a cautious and reluctant approach to lawmaking that recognizes ethnic difference,"

30. Peek, "Japan, the United Nations, and Human Rights," pp. 217-29.

31. On both cases, see Iwasawa, "The Domestic Impact of International Human Rights Standards," pp. 260-65. 
politics of recognition has spawned the politics of universalism or equal dignity that supports calls for the equalization of citizen rights and entitlements. Under this conception of the politics of recognition, the distinction between "first-" and "second-class" citizens constitutes the greatest affront to members of the same political community. Taylor argues that the politics of recognition, however, has also engendered the politics of difference or particularism that leads to demands for special rights and acknowledgement of distinctness rather than common rights and entitlements. Under this view, the idea of an assimilated identity constitutes the greatest affront to members of distinct groups within the same political community.

At the heart of the struggles for both equal dignity and recognition of difference is the question of what it means to be Japanese. Political elites consistently use a mono-ethnic conception of "Japanese-ness" to justify the exclusion and unequal treatment of ethnic minorities. Richard Siddle notes that the myths of Nihonjinron (discourses on Japanese-ness) posit "a neat and unproblematic overlap between nationality and Japanese ethnicity, itself an inherently essential and 'racialized' concept that encompasses widely held beliefs in 'Japanese blood'." 33 Such a conception of Japanese-ness creates distinct problems for both kinds of politics of recognition.

Conflating Japanese ethnicity, national identity, or nationality has led to the exclusion of non-ethnic Japanese from the full rights of citizenship. International human rights norms have helped nonethnic Japanese in their domestic struggle for equal political, civil, and social rights. At the same time, however, the acquisition of such rights does not seem to guarantee equal dignity, if they require embracing a conception of Japanese-ness that denies or devalues ethnic and social "others" within Japanese society. The development of international human rights norms has increasingly focused on buttressing claims of distinctness, especially of indigenous peoples, in order to help such groups achieve inclusion without assimilation.

32. See Charles Taylor, "The Politics of Recognition," in Amy Gutmann, ed., Multiculturalism: Examining the Politics of Recognition (Princeton: Princeton University Press, 1994)

33. Siddle, "The Limits of Citizenship in Japan," p. 448.

\section{The Internationalization Movement} as a Policy Response To Social Diversity

Japanese attempts to come to terms with internal social diversity have also involved local government and grassroots citizen initiatives. The experience of the Second World War made some Japanese aware of the importance of promoting direct exchanges with the international community rather than leaving international exchange up to the government, as was the case before the war. Aiming at international goodwill and rapprochement with the rest of the world, international exchange activities gradually began to be conducted throughout the whole country from the 1950s onward.

\section{Exchange Programs}

It was Americans who broke the ice for the Japanese by kickstarting international exchange after the war. After the Second World War a defeated and occupied Japan looked to America for keys to its rejuvenation in international society. The importance of English language education was internalized by the whole population, and learning English-formerly regarded as the language of the enemy-turned into a fad, even among ordinary citizens. ${ }^{34}$ In 1956, Dr. Donald B. Watt, founder of the American private association Experiment in International Living, brought five American women on a visit to Japan and organized the first home-stay in Kanazawa, away from war-ravaged Tokyo. ${ }^{35}$ At that time it was unthinkable that Americans would stay in Japanese people's homes, and it was recorded as an extraordinary experience. The people-to-people exchange activities made a great impact on the people of Kanazawa, who later decided to establish a Japanese branch of Experiment in International Living in Kanazawa with the help of the governor and mayor.

In 1955 the sister-city alliance between the City of Nagasaki and St. Paul in the United States was founded. Later, sister-city partnerships came to be established through the active efforts of

34. The English conversation text, Nichibei Kaiwa Techo, was published one month after the end of the World War II and sold 3.6 million copies.

35. 45th Anniversary Chronicle of Kanazawa EIL (publisher, year unknown). 
both Japanese and American local governments. Although these partnerships with foreign cities were actively promoted in the 1960s, it was still rare to spot foreigners even in major Japanese cities, and travel abroad was limited to a handful of Japanese citizens. ${ }^{36}$ Local governments thus had created an important avenue for ordinary citizens to raise their awareness of foreign countries and to come directly into contact with foreigners whom they knew previously only through mass media. At that time, more than half of the sister-city partnerships were with cities in Ameri$\mathrm{ca}$, and on the foundation of these exchanges the longing of Japanese citizens for America, its culture and lifestyle, took root.

Local governments continued to play the leading role in international exchange at the community level in the 1970s. During that decade, Japanese citizen groups promoting international exchange were still immature. However, among the heads of local governments, there were many who eagerly embraced international exchange. They thought that providing ordinary people with opportunities to experience other cultures was essential for the development of Japan's future and that it was necessary to bring new technology and ideas into local governments and communities through international exchange.

Through the 1970s the word "internationalization" gradually spread. As Japan underwent remarkable economic development and emerged as the world's second-largest economy, people in local governments believed it more important for Japanese citizens to hold an interest in international affairs, and that it was their responsibility to further international exchange activities. Internationalization constituted one of the three major societal transformations at the time, alongside the growth of the information economy and the aging of society. Local governments vigorously addressed the internationalization issue, often holding international seminars by inviting foreign guests and other international exchange activities.

By the 1980s trips abroad became an ordinary event for the average Japanese citizen. In addition, the sister-city exchanges became even more lively. By the end of the 1980s, almost 800

36. In 1964 traveling abroad was liberalized and 99,049 people made an overseas trip that year. In contrast, 13.3 million Japanese traveled abroad in 2003. local governments had formed sister-city alliances.

\section{"Internationalization"}

It was at this time that international exchange turned almost into a boom, and under catchphrases such as "internationalization of the countryside" and "internationalization of the regions," the number of local governments independently investing efforts to forward internationalization increased. In the Hometown Revitalization Project of 1988, in which 100 million yen was distributed to all communities in the country by the national government, many local governments used these funds for international exchange activities, in particular for event-oriented international exchanges, with the goal of revitalizing the region.

In 1983, the "100,000 Foreign Students Plan" was drawn up by the national government to increase the number of foreign students coming to Japan by the beginning of the twenty-first century, and slowly the number of foreign students at universities across the country started to rise. Local citizen groups responded to the influx of mainly Asian foreign students by organizing exchange and living support activities. At the same time a number of East Asian and Southeast Asian cities, mainly in China and Korea, became Japanese sister-city partners. It was in the 1980s that for the first time communities in Asia started to feel closer to each other. Before that time Japan's interest in outsiders had been monopolized mostly by the United States and Europe.

Acknowledging that regional internationalization had become a nationwide boom, the former Ministry of Home Affairs (currently Ministry of Public Management, Home Affairs, Posts and Telecommunications) and the foreign ministry initiated various policies specifically to support international activities conducted by local governments.

In 1986, the foreign ministry set up a consultation center for internationalization that began to provide information for and facilitate international exchange by local governments. The former Ministry of Home Affairs also notified prefectures of the "Guidance for the Conduct of International Exchange by Local Governments," which illustrated the basic policy framework for international exchange for local governments and signified a new recognition by the national government that international 
exchange as carried out by local governments was an important means of regional revitalization.

In the first half of the 1990s, the impact of the bursting of the "economic bubble" on international exchange and cooperation activities was minimal, and 1992 witnessed the registration of a record eighty new sister-city alliances. ${ }^{37}$ However, in the latter half of the 1990s, local governments and international exchange associations were hit by the sluggish economy and their budgets for international exchange and cooperation activities were cut, causing them to revise their activities and reevaluate their projects.

\section{Foreigners and Multiculturalism}

Contemporary local or regional initiatives promoting international exchange stem from recognition of changing relationships between Japan and other countries in an era of globalization. For many decades Japanese people commonly presupposed that there was a certain distance between Japan and other countries. Their model of international exchange presumed that Japanese would cross the sea from the Japanese islands to interact with foreigners and then come back, and that foreigners should be invited to Japan as visitors only to return to their home countries soon afterwards-an assumption similar to that of the Meiji leaders vis-àvis their foreign travels and their foreign advisors. In this sense international exchange for Japanese society was conceived to be a one-time event, cut off from daily life; the internationalization approach implicitly aimed to select desirable features from foreign countries and incorporate them into Japan.

With rapid globalization the presumed control of Japanese communities over external influences eroded. Both welcome and unwelcome influences from abroad are felt not only in people's everyday lives in large cities, but also in smaller towns and villages. How communities should cope with the new consequences of globalization that dynamically change people's lives has become a major concern.

The increasing long-term presence of foreigners has begun to have a marked effect on Japanese society. Many of the local gov-

37. Japanese Local Government International Affiliation Directory 2000, Council of Local Authorities for International Relations (CLAIR). ernments that independently conducted international exchange programs have now established international exchange associations to deal with these changes within their communities and to carry out international exchange efforts in a coordinated manner.

The establishment of international exchange associations was proposed to the prefectures by the former Ministry of Home Affairs in 1989 through the "Guidelines for the Local International Exchange Promotion Plan." It requested that local governments establish the associations as the core organizations for the promotion of local internationalization activities. Consequently, such organizations were set up one after another in all prefectures. Today, even small local governments have international exchange associations, which now number more than 900. Most such associations cite promotion of international exchange activities through citizen participation as their goal, but some of them aim specifically to foster mutual understanding between foreign residents and Japanese citizens. Together with local governments, the international exchange associations have played an important role in supporting local citizens to meet the new challenges wrought by globalization.

Apart from those connected to local governments, many other volunteer international exchange organizations exist in various areas of Japan. Their efforts to promote intercultural understanding have helped diminish prejudice and xenophobia to some extent. Such activities have laid the foundations for enabling Japanese to meet the various challenges of increasing social diversity, in particular the increase of foreign residents.

At the same time, some Japanese have come to embrace the notion of global citizenship. The term "global citizen," originally coined by NGOs, began to take root in Japan in the 1990s. It describes people who are interested in global issues such as world peace, the environment, and improving the lives of people in developing countries. Since the 1980s NGOs have sprung up all over Japan, focusing their activities on devising support programs for the poor in developing countries. These activities have served to broaden and deepen the consciousness of Japanese towards others, and have become an important source of Japanese experience with cultural differences. Global citizens are also committed to carrying out activities for improving the global human condition by starting at the grassroots level. The expression "global citizen" 
is widely used not only by NGOs engaged in international cooperation, but also by citizens' groups and local governments promoting international exchange. Most prefectural governments have set up a policy framework for international exchange and the policy framework of seven prefectures explicitly uses the term "global citizen." 38 The fact that such a term has spread in Japan to a certain extent suggests that Japanese have been prepared somewhat not only for limited exchange with foreign countries, but also for living together with foreigners.

Still, the idea of "multicultural coexistence" is hotly contested. At this time there is still no serious recognition among Japanese that Japan is in fact a "multicultural society." Lack of official or mainstream recognition of this fact, coupled with shrinking local government budgets for international exchange activities that promote intercultural understanding and multicultural coexistence, makes it difficult for Japanese to grapple with the implications of this development for the future structure and character of Japanese society.

It is not a given that coexistence of foreigners and Japanese will go smoothly. Even though past efforts supporting international exchange have created a basis for accepting foreigners into Japanese communities, changing citizens' conceptions of Japanese identity to incorporate the idea of multiculturalism, and improving governmental policies affecting foreigners within Japan are required.

Without progressive national political leadership on this issue, ordinary citizens will continue to worry about an increase in crimes committed by foreigners, especially Chinese. This gives rise to a stronger inclination to reject foreigners. Although serious "boycott foreigners" movements and hate crimes, as they occur in the United States and Europe, have not yet been observed, various small clashes owing to opposition to the increase in foreigners are taking place on a daily basis. It would not be surprising to see a series of hate crimes occur in Japan at some point in the near future if national efforts supporting multicultural accommodation are not developed and implemented.

38. 2002, Kokusai Koryu Kikin, Chiho Jichitai niokeru Kokusaika Kokusai Koryu Sesaku no Genjo (The Current State of Internationalization and International Exchange Programs by Local Authorities).

\section{Alternative Futures for Japanese Citizenship}

From the foregoing we have seen how Japan's increasing involvement in international community in recent decades has wrought changes in Japanese society and in its citizenship regime. Some of these changes, such as accession to human rights conventions and support for the internationalization movement, were consciously embraced by the national government as measures that would strengthen Japan's membership in international society. Other changes, particularly the rise of immigration during the "bubble economy" and the continued immigration of Nikkeijin thereafter, emerged out of Japan's position of strength in the international economy and its increasing enmeshment in the dynamics of economic globalization. Both sources of change have had unintended consequences, sometimes unwelcome consequences for the shape of Japanese society and the development of Japanese understandings of national identity and citizenship.

In this, Japan is in good company: To varying degrees, all industrialized constitutional democracies have been confronting the demographic and legal changes that flow from globalization and the rise of international law in the postwar period. In Europe, the evolution of the European Union and the extension of EU membership have brought questions of immigrant rights, citizenship rights, and the rights of national minorities to the fore of intellectual and political debate. The growing transnational movement for indigenous rights, and the growing recognition of such rights in international law, have strengthened the voice of indigenous peoples in Canada, Australia, and New Zealand, with the result that domestic laws concerning indigenous peoples are in a period of significant change in those countries. Secessionist movements in Canada and elsewhere have also heightened awareness of the claims and interests of national minorities within constitutional democracies.

The question confronting Japan in the early twenty-first century is how it will respond to these broad forces of change. To date, the policy response to the reality of immigration has been strongest at prefectural and municipal levels of government. There, we see evidence of a growing will among Japanese people to extend social and political rights to foreign residents and to accept cultural diversity as part of the fabric of Japanese society. 
In contrast, national policy on immigration and citizenship has tended to fall back on the ideology of a homogenous Japanese nation, as demonstrated most clearly in the move to Nikkeijin immigration as a way to bolster the shrinking labor force. With respect to Ainu claims for indigenous rights and Okinawans' claims for greater cultural and political autonomy, there has been some movement in national policy toward recognition of these communities' cultural distinctiveness, but a clear reluctance to recognize any claims that would, in its view, weaken the sovereignty of the Japanese state. It remains very much an open question whether Japan will ultimately choose to follow the path staked out by local governments or the one expressed in national policy, but it does seem clear that this choice cannot remain open indefinitely. Indeed, should the current economic recovery quicken, it may not be long before the question of immigration must become a higher priority in the national policy agenda.

Should Japan choose the path of accepting internal diversity as a permanent feature of its society, and doing so on terms that are consonant with ideals of democratic egalitarianism, it will need to reframe some of its current laws and practices. In doing so, it may benefit from the citizenship policy responses fashioned by other democratic societies encountering phenomena of cultural diversity. In the remainder of the article, we will briefly sketch some of the recent innovations in the theory and practice of citizenship that have been sparked by this encounter.

\section{Denizenship and Citizenship}

In his famous essay "Citizenship and Social Class," British historian T. H. Marshall outlined a developmental account of egalitarian citizenship in Britain. ${ }^{39}$ For Marshall, meaningful citizenship entails treating every individual as a full and equal member of society. But meaningful egalitarian citizenship did not spring full-grown from Enlightenment ideals of universal equality. Rather, Marshall argued, it developed as a gradual expansion of the content of the rights of citizenship and a concomitant exten-

39. T. H. Marshall, "Citizenship and Social Class," in Citizenship and Social Class and Other Essays (Cambridge: Cambridge University Press, 1950), pp. 1-85. sion of citizenship status from property-holding white males to workers, to women, and to minorities. In the eighteenth century, citizenship was understood principally as a bundle of civil rights -the right to own property, above all, but also rights to the freedoms of religion, of the press, and of mobility. In the nineteenth century, citizenship came to include political rights, especially the right to vote, which was initially limited to men and later extended to women. In what Marshall viewed as the final and full development of citizenship rights in the twentieth century, citizenship came to encompass social rights, such as public education, health care, unemployment insurance, and pensions.

Marshall regarded each of these stages of citizenship development as contingent on the one that preceded it, and until recently the temporal relationship between the different types of rights was widely taken as a given for other societies as well. Recent research on rights structures in Europe, however, has undermined the temporal thesis. As Yasemin Soysal argues, the experience of Germany and other European countries reveals a system of rights in which immigrants and former "guest workers" enjoy extensive civil and social rights-sometimes the same bundle of rights enjoyed by full legal citizens-without necessarily having access to political rights. Increasingly, she argues, civil and social rights are attached to long-term residence or denizenship within a country rather than to formal citizen status. ${ }^{40}$

From a normative standpoint, the underlying rationale for adopting a regime of denizenship rights is that these non-citizen residents are, for the foreseeable future, contributing members of society. The principle of equality requires that receiving countries recognize them as such even if full citizenship status lies beyond reach. Increasingly, scholars and activists argue that denizenship should entail not only equal civil and social rights, but also political rights within local communities, as is indeed happening in many democratic societies-including, as we have seen, some municipalities in Japan. In this scenario, the only right that distinguishes full citizens from denizens is the right to vote in national elections.

In the Japanese context, adopting a policy of denizenship rights

40. Yasemin Soysal, Limits of Citizenship: Migrants and Postnational Membership in Europe (Chicago: University of Chicago Press, 1994). 
would require erasing all legal distinctions between Japanese nationals and permanent residents with respect to rights against discrimination (including the sphere of employment) and the full range of social rights, including housing, health care, education, unemployment insurance, and pensions. As discussed above, local governments have increasingly recognized the rights associated with denizenship, including access to education, the national health service, public housing, and voting rights in local elections. Yet these gains for foreign residents are tenuous because economic hard times have forced local governments to cut their budgets for internationalization programs. ${ }^{41}$ Denizenship status cannot be secure unless it is established in national legislation. A full-blown denizenship policy would also ease access to permanent resident status for the many foreign residents who are de facto lifetime members of Japanese society.

Reform to Japanese citizenship laws may also be in order. Increasing numbers of democratic countries are permitting dualcitizenship status in recognition of the fact that individuals may wish to retain ties to their countries of origin while functioning as full citizens in their adoptive countries. With respect to long-term foreign resident populations, especially Koreans who arrived in Japan during the colonial period and their descendants, the burden of choice between Japanese and Korean citizenship is particularly heavy. Given a history in which Japan stripped them of their citizenship and in which they have suffered discrimination in Japanese society, many Korean residents are understandably reluctant to abandon Korean citizenship in favor of Japanese citizenship, especially because of the strong assimilationist pressures built into the naturalization process in Japan. Even if Japan is not prepared to allow dual citizenship for all immigrants, there may be strong reasons to permit it in the case of former colonial subjects and their descendants.

Whatever Japan's decisions regarding dual citizenship, it seems clear that Japanese naturalization regulations are ripe for reform as part of a broader national immigration policy. Although

41. See Toshihiro Menju, "International Policies of Local Governments," in Shun'ichi Furukawa and Toshihiro Menju, eds., Japan's Road to Pluralism: Transforming Local Communities in the Global Era (Tokyo: Japan Center for International Exchange, 2003), p. 94 "guest worker" programs are common in Western democracies, they often face the moral and practical difficulties that Japan has encountered in its trainee program. Individuals stay beyond their term of contract because their opportunities in the receiving country are better than in their countries of origin, and the receiving country has little incentive to deport them because of both administrative complexities and the important role they play in the domestic economy. Children born to guest workers may have rights to citizenship or at least to health care and education that their parents do not enjoy, which places host states in the difficult moral position of deciding whether to deport families, some of whose members are legal citizens. Where guest worker populations have persisted as intergenerational communities, there is ample reason to extend access to permanent resident or citizenship status. An immigration system can avoid these challenges by placing minimal reliance on "temporary" foreign workers, beginning from the supposition that most immigrants will be eligible for permanent resident status, and assuming that all permanent residents will be eligible for naturalization. A principled policy of immigration would state clearly the criteria for preferring some applicants for immigration over others. Naturalization policy should avoid the appearance as well as the reality of arbitrariness in citizenship decisions, perhaps by instituting an appeal board for cases where citizenship is refused, or by offering reasons for refusal to unsuccessful applicants. This is not to say that these requirements are fully met even in traditional "countries of immigration" such as Canada and the United States, but they are clear desiderata of a coherent and principled immigration and citizenship policy.

\section{Multicultural Citizenship and National Minorities}

Since the late 1980s, democratic theorists have increasingly questioned the ideal of universal citizenship interpreted as the same bundle of rights for all citizens. ${ }^{42}$ The flaw in this ideal, they argue, is that there is no such thing as a universal standpoint from which to define the meaning of citizenship. All social agents, including legislators and judges, reach judgments about

42. See especially Iris Marion Young, Justice and the Politics of Difference (Princeton: Princeton University Press, 1989). 
the meaning of broad principles of equality from a specific social perspective. Ideals of equality and freedom are too abstract, too indeterminate, to provide the full content of citizenship laws and practices. Historically, the content of actual laws and practices has been provided by leaders and legislators who occupy privileged positions in the social, economic, and cultural hierarchy.

On this argument, a truly egalitarian system of law requires that members of disadvantaged groups participate in framing laws, and that sources of legal bias-on grounds of gender, "race," class, religion, or culture-be actively challenged. In doing so, we might sometimes find that treating individuals as equals requires treating them differently from other groups of citizens. Standard (and relatively easy) examples of such "differentiated citizenship" include exemptions for Jews and Muslims from laws requiring the Sunday closing of businesses, or allowing Sikh officers of the Royal Canadian Mounted Police to wear buff-colored turbans instead of the standard Stetson hat.

For defenders of "differentiated citizenship," antidiscrimination law is still a necessary feature of equal citizenship, but it is no longer considered sufficient. For groups characterized by systemic or structural inequality, for example, a passive principle of formal equality will not be sufficient to reverse historic patterns of disadvantage. Instead, there is a need for "positive" or "affirmative" action to bring about structural change. In the Japanese case, we see these ideas at work in the Dōwa programs aimed at promoting targeted educational opportunities for burakumin and introducing the buraku issue into school curricula to combat tendencies toward social discrimination.

Redressing social and economic disadvantage is one dimension of a diversity-responsive approach to citizenship; redressing cultural marginalization is another. Among recent democratic theorists, Canadian political philosopher Will Kymlicka has been especially influential in shaping the theoretical debates around citizenship in multicultural societies. Kymlicka begins from the claim that membership in a cultural community strongly shapes our individual capacities to live fulfilled and self-directed lives, since it is culture that gives meaning to the life-choices that are available to us. The realization of individual autonomy, in his view, requires that individuals have access to the cultures that are meaningful for them. For immigrant groups, this means that we should distinguish sharply between policies of integration and policies of assimilation: The goal should be to enable the full and equal membership and participation of immigrants in the receiving society, not the erasure of their cultural distinctiveness as such. Policies that affirm immigrants' cultural identities, he argues, actually serve a positive integrative function because they enable immigrants to feel that they can participate fully in society without having to deny their own self-understandings. Kymlicka gives the label "polyethnic rights" to the rights that can serve this integrative function, such as access to public services and to all legal processes in one's native language, exemptions from laws that disadvantage a minority because of its religious beliefs or cultural practices, public resources for cultural festivals, publicly funded education in minority languages. ${ }^{43}$

In the Japanese context, local governments' practices demonstrate a clear effort to secure some polyethnic rights for minorities. Many have established social services and legal services in foreign residents' mother tongues, and language and cultural education for children within public schools. Some have established cultural community centers and provided support for cultural festivals, especially for the Korean community. As noted above, however, the funding for these programs is tenuous, particularly in times of recession. And because they are local policies, there is considerable variation across Japan in the degree to which foreign residents can benefit from them. A national integration policy could provide these integrative benefits on a more secure and reliable basis.

Kymlicka distinguishes the cultural claims of immigrant groups from those of national minorities, which he generally defines as culturally distinct communities whose existence on a territory predates the formation of the state. In contrast to most immigrants, many national minorities (including indigenous groups) were incorporated into the state involuntarily; they never consented to abandon their cultural distinctiveness and to adopt the cultural identity of the majority within the newly formed state. Historically, many national minorities have been subject to harsh assimilationist programs, often with devastating

43. Will Kymlicka, Multicultural Citizenship (Oxford: Oxford University Press, 1995), pp. 30-1. 
social and psychological costs. Frequently they have been subject not only to assimilation but also to second-class citizenship within the state that seeks to absorb them. Yet the assimilation programs characteristic of nineteenth-century state building have often failed to erase cultural differences, with the result that members of national minority groups do not have secure access to a culture that can provide meaning for them: They have been denied the right to sustain their own culture, but they are not at home in the majority culture. For such communities, the only solution short of secession is a set of special rights that will enable them to restore and sustain their cultures. These rights commonly include significant local political autonomy on their traditional territory; the recognition of their traditional language as an official language within the territory they occupy; education in their traditional language; economic rights (including, for example, special hunting and fishing rights for indigenous communities); and rights of special representation in local and national political bodies.

In the Japanese context, both the Ainu and the Okinawan people constitute clear national minorities within the terms of these arguments. For Okinawans, the most urgent issues are enhanced local autonomy, enhanced programs for language rights and education in the vernacular dialects, the reduced influence of U.S. military bases on Okinawan society, and restitution for lands taken for those bases.

As an indigenous people, the claims of the Ainu are somewhat different. They too seek enhanced local autonomy and restitution for the taking of their traditional lands by the Japanese state. They also seek-and, with the 1997 legislation, have attained to some degree-language and education rights and programs to recognize and encourage Ainu culture. Beyond this, however, they seek special rights to representation in legislative bodies at the local and national level-rights they have not yet received. Here the circumstance of the Ainu is similar to that of indigenous peoples of Canada (outside Nunavut), despite proposals for Aboriginal representation in the Canadian Parliament and for the creation of a Congress of First Peoples. Special representation rights for indigenous peoples have been established for the Sami in Norway and Sweden (Sami parliaments) and for the Maori in the New Zealand national parliament, and these pro- vide useful models for thinking through the possibilities for the Ainu in future legal reforms.

Not surprisingly, contestation at the international level over the legitimacy of collective and indigenous rights becomes a tool for official Japanese resistance against domestic recognition of such claims. As Richard Siddle has observed, "The Japanese government has been consistent in denying the principle of collective group rights on the grounds that it would infringe Japan's constitutional guarantees that all citizens be treated equally, and is moreover without precedent in international law." ${ }^{\prime 4}$ Indeed, most member states of the UN, jealous of their sovereignty and territorial integrity, do not endorse rights of indigenous peoples to selfdetermination. Such an international context means that Japanese recognition of the Ainu as an indigenous people with rights to self-determination is not likely to be forthcoming without a decisive normative consensus at the international level.

\section{Conclusion}

Japan's historical encounter with cultural difference has been a mixed story, one whose internal tensions have still to be resolved. Japan appears to be torn between strong ideas of national homogeneity as a fact and as beneficial for the stability of Japanese society, on the one hand, and ideals of egalitarianism, universalism, and global citizenship, on the other hand. The tensions between these two strands of thought about membership come to the fore when we consider the absence of a clear or coherent immigration policy at the national level. Despite the internationalization movement's strong impulses toward egalitarianism and culturally sensitive integration of minorities, there has not been clear leadership at the national level. Because these issues cannot be fully met by local governments, but need national immigration and citizenship policy, the time appears ripe for national reform. Undertaking such reform would also create a moment of opportunity for other diversity-responsive policy changes vis-à-vis the Ainu, burakumin, and Okinawans.

Admittedly, the current mood in Japan does not appear pro-

44. Siddle, "The Limits of Citizenship in Japan," p. 457. 
pitious for egalitarian reform in policies affecting minority populations. In this, too, Japan bears some similarities to European countries, where there is now a backlash against "asylum seekers" and a rise of anti-immigrant sentiment. Yet to the extent that political leaders fan the flames of xenophobia, or succumb to political pressure to embrace it, they engage in a willful blindness to the current and future diversity of modern societies. A principled response to diversity does not require an abandonment of agency to shape political community so as to foster solidarity and stability, as so many now fear. To the contrary, solidarity and stability will remain elusive as long as governments fail to reconcile the fact of diversity with aspirations to democratic equality and human rights.

The era of globalization has produced increasing social diversity within Japanese society, forcing a reexamination of mainstream assumptions about Japanese national identity and citizenship. The fact of social diversity presents Japanese people, as well as most other citizens of liberal democracies, with a potential ingredient for social crisis and conflict or social growth and opportunity. Japan's capacity to harness the fact of social diversity into a revitalizing and socially constructive force in Japanese society will depend on the ability of its political leaders to enact and implement citizenship policies that confirm the equal dignity of social "others," as well as the ability of its citizens more broadly to adopt heterogeneous rather than homogeneous notions of Japanese national identity.

\section{Principal References}

Chung, Erin Aeran. "Exercising Citizenship: Koreans Living in Japan," Asian Perspective, vol. 24, No. 4 (Winter, 2000), pp. 159-78.

Doak, Kevin M. "Ethnic Nationalism and Romanticism in Early Twentieth-Century Japan," Journal of Japanese Studies, vol. 22, No. 1 (1996), pp. 77-103.

Hur, Claire J. "Comment: Returnees from South America: Japan's Model for Legal Multiculturalism?" Pacific Rim Law \& Policy Journal, vol. 11, No. 3 (June, 2002), pp. 669-71.

Iwasawa, Yuji. "The Domestic Impact of International Human
Rights Standards: the Japanese Experience," in The Future of UN Human Rights Treaty Monitoring. Cambridge: Cambridge University Press, 2000, pp. 245-68.

Kajita, Takamichi. "The Challenge of Incorporating Foreigners in Japan: 'Ethnic Japanese' and 'Sociological Japanese',"' in Myron Weiner and Tadashi Hanami, eds., Temporary Workers or Future Citizens? Japanese and U.S. Migration Policies. New York: New York University Press, 1998.

Kashiwazaki, Chikako. "Jus sanguinis in Japan: The Origin of Citizenship in a Comparative Perspective," International Journal of Comparative Sociology, vol. 39, No. 3 (1998), pp. 278-301.

Kondo, Atsushi. "Citizenship Rights for Aliens in Japan," in A. Kondo, ed., Citizenship in a Global World: Comparing Citizenship Rights for Aliens. New York: Palgrave, 2001, pp. 8-30.

. "Development of Immigration Policy in Japan," Asia and Pacific Migration Journal, vol. 11, No. 4 (2002), pp. 415-36.

Kymlicka, Will. Multicultural Citizenship. Oxford: Oxford University Press, 1995.

Levin, Mark. “Essential Commodities and Racial Justice: Using Constitutional Protection of Japan's Indigenous Ainu People to Inform Understandings of the United States and Japan," New York University Journal of International Law and Politics, vol. 33, No. 2 (2001), pp. 419-526.

Marshall, T. H. "Citizenship and Social Class," in Citizenship and Social Class and Other Essays. Cambridge: Cambridge University Press, 1950, pp. 1-85.

Menju, Toshihiro. "International Policies of Local Governments," in Shun'ichi Furukawa and Toshihiro Menju, eds., Japan's Road to Pluralism: Transforming Local Communities in the Global Era. Tokyo: Japan Center for International Exchange, 2003.

Papademetriou, Demetrios G. and Kimberly A. Hamilton. Reinventing Japan: Immigration's Role in Shaping Japan's Future. Washington, D.C.: Carnegie Endowment for International Peace, 2000.

Peek, John M. "Japan, the United Nations, and Human Rights," Asian Survey, vol. 32, No. 3 (March, 1992), pp. 217-29.

Siddle, Richard. "The Limits of Citizenship in Japan: Multiculturalism, Indigenous Rights and the Ainu," Citizenship Studies, 
vol. 7, No. 4 (2003), pp. 447-62.

Soysal, Yasemin. Limits of Citizenship: Migrants and Postnational Membership in Europe. Chicago: University of Chicago Press, 1994.

Taylor, Charles. "The Politics of Recognition," in Amy Gutmann, ed., Multiculturalism: Examining the Politics of Recognition. Princeton: Princeton University Press, 1994

Weiner, Michael. Race and Migration in Imperial Japan. London: Routledge, 1994.

Yamawaki, Keizo. "Foreign Workers in Japan: A Historical Perspective," in Mike Douglass and Glenda Roberts, eds., Japan and Global Migration: Foreign Workers and the Advent of a Multicultural Society. London: Routledge, 2000.

Yonetani, Julia. "Future 'Assets,' but at What Price? The Okinawa Initiative Debate," in Laura Hein and Mark Selden, eds., Islands of Discontent: Okinawan Responses to Japanese and American Power. Lanham, M.D.: Rowman \& Littlefield, 2003. 